\title{
Biopolitical Production of Human Security and Inclusion/Exclusion of State Security, Human Rights, and Human Development
}

\author{
$1^{\text {st }}$ Rizma Afian Azhiim \\ Department of International Relations \\ University of Indonesia \\ Depok, Indonesia \\ afianazhiim@gmail.com
}

\author{
$2^{\text {nd }}$ Laila Anggita Nurcahyani \\ Department of International Relations \\ University of Indonesia \\ Depok, Indonesia \\ laila.anggita15@gmail.com
}

\begin{abstract}
This article examines human security as a discourse which existed from structural inclusion/exclusion of state security, human rights, and human development. Drawing from the work of Michel Foucault, Giorgio Agamben, and other thinkers that stressed in developing the concept of biopolitics, the article argues that human security was biopolitically produced through the structure of inclusion/exclusion of state security and human development. The methodology is applied by a poststructuralist philosophical foundation which considers the importance of linguistic ontology and discursive epistemology to understand the existence of the phenomenon. Its examination begins with an analytical exploration of juridical discourse that represents the international authority which amenable to define human security as a form of international security urgency. The article finds out that the inclusion/exclusion of state security and human development contribute to the exercise of power by defining the authority of international interventions to secure human life.
\end{abstract}

Keywords-biopolitics, human security, state security, human rights, human development.

\section{INTRODUCTION: THE PARADOX OF HUMAN SECURITY}

The term secure and insecure is on the same point as the term beautiful and ugly. Security is a subjective and elastic term; meaning exactly what the subject in questions says its means [1]. Security is not an independent concept [2], but it is an 'essentially contested concept' [3]. Security often appears and being used in a power contest to raise consciousness on people's mind about what is being labeled as a threat [4], and it is always related to individual or societal value systems [5]. This research is a result of a study which reflects how human security is given meanings through two processes. First, a set of the process through biopolitical production that operates with managing, securing, and promoting people's life, by giving them the freedom to do the control and self-disciplining [6]. The second one is a process through the inclusion/exclusion articulation structure; which is a meaning system through a metaphor space that is used by political power to decide a meaning of something [7].

In the last two decades, the international security concept has started shifting from state security dimension to human security. Ever since the Cold War ended, the United Nations institution (UN) has voiced out a narration about the security threat of human living conditions. The narration itself started to be announced through Human Development Report in 1994 as human security, which discoursing the security of human life in the scope of economic, health, living environment, individual, group or community, and political security as well as the human rights. Human security narration is an international security agenda which raised its head through an international political process and is applied by the UN. The UN voices the discourse about human security for every subject in the world can understand and realize the importance of keeping and conserving the human life in the scopes mentioned.

Through the jargons such as freedom from fear, freedom from want, and freedom to live in dignity, human security is always discoursed by the UN and the entities inside to build the awareness on the importance of securing human life [8]. The UN assumes that human security is a new vision in seeing the international security context in the $21^{\text {st }}$ century [9]. The $\mathrm{UN}$ also assumes that human security is a kind of new security paradigm which is not centered on the state, but on the citizens instead. Different from the traditional security approach from state security with a focus on direct threat towards a state which generally takes a form of military power attack, Human Security positioning its concern in any form of threats toward individual or community life. Human security is claimed as a concept of security that focuses on protecting the vital core of all human lives in ways that enhance human freedoms [10]. The UN through its bodies such as United Nations Trust Fund for Human Security (UNTFHS) which is established in 1999 , Commission on Human Security (CHS) in 2001, Human Security Unit (HSU) in 2004, and other bodies have tried to put Human Security as an international security agenda [11].

The application of human security as an international security agenda by the UN is in fact beyond the international security paradigm which underlies one of the UN establishment's purposes, as included in article 1 number 1 of UN Charter: 
"The Purposes of the United Nations are (1) To maintain international peace and security, and to that end: to take effective collective measures for the prevention and removal of threats to the peace, and for the suppression of acts of aggression or other breaches of the peace, and to bring about by peaceful means, and in conformity with the principles of justice and international law, adjustment or settlement of international disputes or situations which might lead to a breach of the peace [12];"

Article 1 number 1 of UN Charter above shows how international security paradigm which is adopted by the UN focuses on the violation threats toward peace, or in other words: a threat which can cause war or armed conflict. The article even mentioned that one of action related to security and international peace is international disputes. What is meant as international disputes in the article are actions that may endanger the maintenance of peace as well as international security, as included in the phrase in article 34 of the UN Charter:

"The Security Council may investigate any dispute or any situation which might lead to international friction or give rise to a dispute, in order to determine whether the continuance of the dispute or situation is likely to endanger the maintenance of international peace and security [13]."

Based on the articulation on security which can be found in UN Charter, the existence of human security as a security concept is not suitable with the security paradigm that relates with peace and dispute between nations that can harm peace. Therefore, the existence of human security as an international security agenda, concept, and discourse is a paradox condition in the UN security paradigm. In that paradox condition, it is important to understand on what condition should the UN makes human security as the international security agenda, even though human security concept is beyond the security paradigm which is stated in the UN Charter hitherto.

The UN is an international institution that plays a role as the alignment center of all actions to maintain international security and peace; developing friendship relation among nations based on appreciation on rights equality's principals and the rights to decide one's fate; and hold an international cooperation to solve problems on economics, socials, cultures, and also humanities, including encouraging respect towards human rights and human basic freedoms. The role and purpose of the UN's existence represent a form of power that plays a role in making arrangements in life. In order to understand how that power works, we need to understand what that power is, how that power works, and in what conditioning process can that power exists and goes in life. With biopolitics concept that sees power goes in life (biopower) through disciplining method and regulatory control that 'free' people, we can grasp how power that goes through the $\mathrm{UN}$ is able to act in making arrangements in life; be it life that is related with security and peace, social, economic, culture, and human rights. Therefore, according to the writers, the use of biopolitics concept in the research's analysis framework is meant to facilitate us in understanding what kind of power that goes through the UN, and how that very power works.
The running power needs a certain power system which makes it possible to organize what needs to be organized, regulate what needs to be regulated, and carry out what needs to be carried out through an institution. We need to comprehend in what form and how the UN's authority system is able to organize, regulate, and carry out human security as security agenda which is related in keeping the peace and preventing military aggression and armed conflict. For understanding that, in this paper's analytical framework, the writer adopts R.B.J Walker's thought which said that modern politics is an inclusion/exclusion articulation structure [14]. Through that thought, we could understand how various economic, health, living environment, and human rights issues could be included into security context as well as excluded from their real domains; which are social, economic, development, and human rights domains.

\section{THE UNITED NATIONS AND BIOPOLITICAL PRODUCTION}

"Life has now become . . an object of power [15]."

Biopolitics emerged from Michel Foucault's analysis about transformation mode of power. The first transformation was the re-articulation of sovereign power into biopower, which has happened since the $17^{\text {th }}$ century. Sovereign power is identified by power relation that runs vertically through the forced takeover of life, goods, and property; not to mention expropriation of the controlled subject's life. Meanwhile, biopower is a form of power which operates by managing, securing, and promoting life, and also lets the controlled subject stay alive [16]. The second transformation about the birth of biopolitics is related to what Foucault describes as the emergence of liberal government. What Foucault means as the liberal government is specific arts of government that govern the political subject, which is human individual or population. Liberalism as the art to govern operate by using rationality foundation of society's nature that able to stimulate and persuade the population to actively fill, run, and maintain the authority of power [17].

Basically, Foucault separates two forms of the running biopower, which are individual body-disciplining form and population regulatory control. Biopower in individual bodydisciplining form runs through securing and controlling technology of individual body that is being equated as a machine and not going in a repressive pattern. However, the purpose of discipline is to improve economic productivity from the individual body, and on the other side, weakening their power to ensure political adherence. Biopower in a regulatory control form directed towards collective bodies of the population, which is a social body that is being identified by the social process of human life. Regulatory control runs through the certain technology of security that secures the living process of society and protects the population from internal risks and threats [18].

In order to understand how biopolitical process allows human security to existing as a security concept and being made into international security agenda by the $\mathrm{UN}$, it is needed 
to explore through many discourses, which is related to, biopolitical production. Those discourses are related to the UN juridical formation, which becomes the UN's foundation to runs like a modern political institution; discourses that are capable to give stimulation and persuasion to everybody/population in order for them to comply (such as human rights and human development discourses); and discourses that represents disciplinary practices for the noncompliances.

“.... juridical discourses focusing precisely on the problem of the nature of the sovereign's right to exercise his power and the legal limits within which the sovereign's action can be inserted [19]."

The juridical formation is a constitutional, law, governance, and rationality foundation of the running power system. The juridical formation contains as well as a set of many discourses that represent a modern political institution's rights and authority, and also power scope, which runs based on inclusion/exclusion articulation structure. In this context, the UN juridical formation is an articulation basis from what become rights, authority, the UN's power scope, and legal restrictions that allow the UN to position itself.

On one side, all the UN's juridical formations become a foundation of that international institution's running system in its every member's sovereignty, which is based on the idea about 'international rights' and defined through pacts and treaties. However, on the other side, the UN's legitimating process can run effectively if there is a 'sovereignty' shift from state sovereignty to the real supranational sovereignty center [20]. The 'sovereignty' shift — as a transcendental power that goes through the inclusion/exclusion articulation structure- is definitely not happening totally and not in a short time. It is but happening slowly based on everybody/population from the UN's member nation-states' development of rationality. The sovereignty shifting is an important 'material' that functions as the UN's power support, but cannot be done totally and forcefully because it can cause a potential resistance and danger over latent conflict, also the UN's failure to maintain its existence as a modern political institution. In order to make it possible to be done, the sovereignty shifting must be based on the rationality that able to convince everybody/population from nation-states to exclude some parts from national sovereignty and include them into supranational sovereignty, but without negating those parts in national sovereignty by enclosing national sovereignty in supranational sovereignty's implementation. In understanding that sovereignty shifting process, we need to re-reflect the UN Charter which is the main source from the UN juridical discourse that supports the UN supranational sovereignty.

The UN's existence as an international institution cannot be separated from the UN Charter that becomes a juridical power source that can be implemented at a global level. Through UN Charter as the juridical source, the UN is able to run its functions as the core entity from an international or global juridical structure form. UN Charter also consist a juridical discourse that is allowed to be a rationality foundation to convince everybody/population from nationstates to become constituents or the UN's members, run the UN's functions, and work together to achieve the UN's establishment goals. The juridical discourse can be understood through articulation in the article 1 of the UN Charter:

"The Purposes of the United Nations are:

1. To maintain international peace and security, and to that end: to take effective collective measures for the prevention and removal of threats to the peace, and for the suppression of acts of aggression or other breaches of the peace, and to bring about by peaceful means, and in conformity with the principles of justice and international law, adjustment or settlement of international disputes or situations which might lead to a breach of the peace;

2. To develop friendly relations among nations based on respect for the principle of equal rights and self-determination of peoples, and to take other appropriate measures to strengthen universal peace;

3. To achieve international cooperation in solving international problems of an economic, social, cultural, or humanitarian character, and in promoting and encouraging respect for human rights and for fundamental freedoms for all without distinction as to race, sex, language, or religion; and

4. To be a center for harmonizing the actions of nations in the attainment of these common ends [21]."

From the article 1 of UN Charter above, we can articulate juridical discourse to understand in what condition everybody/population from nation-states become constituents or the UN's members, run the UN's functions, and work together to achieve the goals of the UN's establishment. First, everybody/population from nation-states are convinced that the $\mathrm{UN}$ is an international institution, which maintains international security and peace. That very context contains a discourse which represents hope for everybody/population from nation-states to create peace in order to achieve a sense of security from wars and any armed conflicts that can destroy and snatch human life. The hope to create peace in order to get a sense of security can be achieved if everybody/population from nation-states joins the UN and plays an active role to achieve that hope through the UN's existence. The functioning of the discourse in convincing everybody/population from nation-states can be understood in how the UN imposes sanctions on several states that develop destructive nuclear weapons and threatens life. This includes various dialogues, discussions, and decisions in the UN to stop any acts of aggression by the certain state toward other nation-states, and settle armed conflicts and war among states.

Second, everybody/population from nation-states are convinced that the UN plays a role to develop the friendly relation between states based on the appreciation of rights' equality and the rights to decide one's fate principles. The discourse promises every nation to be recognized as the same as other nations, and not being limited to form a free state and decide their own fate through a government of that nation. The functioning of the discourse in convincing everybody/population from nation-states can be understood in 
how the UN facilitates the referendum for nations that want to be independent, and form a state and their own government.

Third, everybody/population from nation-states are convinced that the UN become a vessel to hold international cooperation to solve economic, social, cultural, and humanity problems; including encouragement towards human rights and basic human freedom. That very discourse represents the UN's existence as an international order which can be used by everybody/population to solve the problems mentioned. The functioning of the discourse in convincing everybody/population from nation-states can be understood in how the UN establishes international development agendas which focuses on tackling poverty and inequality among nations. This includes the birth of many conventions that acknowledge human rights universally, as well as social and political rights, economic rights, and cultural rights.

From those three juridical discourses above, it can be understood that the UN's supranational sovereignty juridical formation is constructed through human life's problem discourses which are related to security and peace, freedom and the rights to choose one's fate, as well as economic, social, cultural, and humanity problems, not to mention basic human freedom. The discourse about those life problems is the rationality foundation on how the mode of biopolitical power and apparatus is produced so that the UN can maintain its existence. Moreover, the discourse about life problems that become the UN's existence foundation also constructs circumstances that are made into the UN's rationality foundation to bring human security up as an international security concept.

\section{HUMAN RIGHTS AND HUMAN DEVELOPMENT DISCOURSES AS} A MODE OF BIOPOLITICAL PRODUCTION

"With regard to the problem of what are currently called human rights, we would only need look at where, in what countries, how, and in what form these rights are claimed to see that at times the question is actually the juridical question of rights, and at others it is a question of this assertion or claim of the independence of the governed vis-a-vis governmentality [22]."

In biopolitics conceptual framework, Michel Foucault sees human rights as one mode of the running power through stimulation and persuasion to convince everybody/population to fill the power, run the power, and maintain the power's order. In the previous part, it is already explained about how human rights and basic human freedom is one of the discourses on life's problem that became the UN's existing foundation. They also constructed circumstances that can be made into rationality foundation for the UN to bring human security up as an international security agenda. In this part, the writers will explain how human rights discourse is produced and plays a role as a mode of biopolitical power and apparatus in supporting the UN's power, and becomes the rationality foundation of the emergence of human security concept.
Since the Universal Declaration of Human Rights (UDHR) was announced by the UN General Assembly on December 10, 1948, through resolution 217 A (III), various human rights and basic human freedoms has been recognized in the global order. The UN's establishment on human rights as universal values gives rationality foundation for the UN to convince everybody/population, as biopolitical power's subject, to fill the power, run the power, and maintain the power's order through four discursive formations. First, discourse about recognition of natural dignity and the same rights for every human being as a basis of independence, justice, and peace all over the world. Second, discourse about inhumanity which can be caused by abandoning acts and underestimating human rights. Third, discourse about the universalization of human rights which has the purpose of the establishment of a world, where human beings enjoy the freedom of speech, the freedom of having religion, and the freedom from fear and deficiency. Fourth, discourse about human rights that need to be protected with the rule of laws, so that people will not be forced to choose revolt as the last retort to go against tyranny and colonialism [23].

Those four discursive formations construct a reality on how human rights must be protected by the rule of laws in supranational sovereign juridical to prevent tyranny and armed conflicts. Moreover, those four discursive formations also construct ideal thought that can be achieved together by everybody/population who becomes the UN's subject of power to create a world order that can guarantee the freedom of speech, the freedom of having religion, and the freedom from fear and deficiency. On the basis of that reality and ideal thought construction, everybody/population is stimulated and persuaded to actively fill, run, and maintain the UN's power order. Therefore, human rights act as a mode of biopolitical power and apparatus in supporting the UN's power and become the rationality foundation of the human security's emergence.

Economy, social, cultural, and humanity problems are one of the discourses on the problems of human life that become the foundation of the UN's existence and construct circumstances which can be made into the UN's rationality foundation to bring human security up as an international security agenda. In this part, the writers will explain how human development discourse is produced and play a role as a biopolitical mode of power and apparatus in supporting the $\mathrm{UN}$, and become the rationality foundation of the human security's emergence.

Human development discourse production, according to the writers, is still closely related to human rights discourse. The establishment of economic, social, and cultural rights (ECOSOC) covenant in 1966 through the UN General Assembly resolution 2200A (XXI) was the UN's rationality foundation to construct a certain circumstance in how the human development is needed. The international covenant of ECOSOC discursively constructs that the ideal circumstance of human beings who are free from fear and poverty can only be reached if a circumstance where every human being can 
enjoy their rights is created. That very circumstance can be achieved through the human rights as well as human development recognition and fulfillment. In human rights' context, it is the rights of every nation to decide their own fate that give them the political freedom to achieve economic, social, and cultural development [24].

The fulfilments of economic and social rights are directed to various human development accomplishment goals which aim to eradicate poverty, inequality, and any threats toward human life. We can take an example on Millennium Development Goals, there are at least eight goals that serve as human development referrals and indicators; which are eradicate poverty and extreme famine; creating basic education for all; promoting gender equality and women empowerment; lowering child mortality rate; improving maternal health; fighting against HIV and AIDS, malaria, and other diseases; ensuring environmental sustainability, and; developing a global partnership for development [25]. Through the discourse of human rights and human development recognition and fulfillment, a certain construction on how ideal circumstance that can convince everybody/population, who become subject of the UN power, to play an active role in achieving that ideal circumstance by filling, running, and maintaining the UN's power order. Based on those things mentioned, human development acts as a mode of biopolitical power and apparatus which become the rationality foundation of the emergence of human security and supporting the UN's power.

\section{THE INCLUSION OF STATE SECURITY, HUMAN RIGHTS, AND HUMAN DEVELOPMENT}

The system of modern political articulation is inseparable from the notion articulation structure between the political and non-political things. The notion from modern political authorities is an inclusion/exclusion articulation system from what is allowed, what is legal and illegal, what is inside and outside, what is being considered as 'us' and as other people, what is urgent and trivial, what is included as political and as social or economy; cultural; biology; privacy. Modern political as an inclusion/articulation system also decides what becomes an authority and what is not, what is categorized as a threat and not threat, what is included in security dimension and what is not, what is included in economic dimension, and what is included in the human rights vice versa [26].

Inclusion/exclusion articulation system has a metaphor space or a space filled with various discursive narration metaphors that produce metaphysical architectures which are equipped with the foundation of rationality, construction, and boundaries between one context and the others. For instance, through inclusion/exclusion articulation structure, what Walker calls as 'international' is a subject that is realized as something outside, or being excluded from modern state sovereignty. Inclusion/exclusion principles are being articulated in various relations between modern state sovereignty system and the international system. Therefore, according to Walker, the so-called 'international' is, in fact, an organization from nation-states modern system which articulates international politic as an inclusion/exclusion structure [27].

The metaphor space in inclusion/exclusion articulation structure, according to Walker, is an imagination that is raised by modern politic - a certain form of knowledge that becomes a rationality foundation from politics - which is regulated through ideas of a context that are restricted by another contexts' boundaries. The boundaries between one context with the others in inclusion/exclusion structure are paper thin. In an inclusion/articulation structure, the practice of power is expressed as an authority claim which sets an articulation of a context and differentiates it from another context. However, because of the boundaries between one context with the others are paper thin, when a context is being articulated by a power authority, that very context cannot remove its relation with the others [28].

Human security, as a security concept, is inseparable from the process of inclusion of state security, human rights, and human development. The security concept of human security discursively related to state security. In fact, the security context of human security is the security and threat context which is excluded from state security; thus, human security is considered as state security's complement. It can be seen in the Commission on Human Security (CHS) report:

\begin{abstract}
"Whereas state security concentrates on threats directed against the state, mainly in the form of military attacks, human security draws attention to a wide scope of threats faced by individuals and communities. It focuses on the root causes of insecurities and advances people-centered solutions that are locally driven, comprehensive and sustainable. As such, it involves a broader range of actors: e.g., local communities, international organizations, civil society as well as the state itself. Human security, however, is not intended to displace state security. Instead, their relationship is complementary: "human security and state security are mutually reinforcing and dependent on each other. Without human security, state security cannot be attained and vice versa [29]."
\end{abstract}

The discourse on the human security's concept of security is also inseparable from the narrations of human development. In fact, there is a context about human security which is excluded from human development context; like economic and financial crisis security, and health security. It can be understood and interpreted from the statements on the Human Security Unit (HSU) report:

“To human development's objective of 'growth with equity,' human security adds the important dimension of 'downturn with security.' Human security acknowledges that as a result of downturns such as conflicts, economic and financial crises, ill health, and natural disasters, people are faced with sudden insecurities and deprivations. These not only undo years of development but also generate conditions within which grievances can lead to growing tensions. Therefore, in addition to its emphasis on human well-being, human security is driven by 
values relating to security, stability, and sustainability of development gains [30]."

Other than state security and human development, the discourse on human security's concept of security is also inseparable from the narration on human rights. In the human security concept, everything that is related to human rights that can cause violent conflicts and threats multidimensionally and comprehensively, become a scope of human security. It can also be understood and interpreted from the statements on HSU report:

“... too often gross violations of human rights result in conflicts, displacement, and human suffering on a massive scale. In this regard, human security underscores the universality and primacy of a set of rights and freedoms that are fundamental for human life. Human security makes no distinction between different kinds of human rights - civil, political, economic, social and cultural rights thereby addressing violations and threats in a multidimensional and comprehensive way. It introduces a practical framework for identifying the specific rights that are at stake in a particular situation of insecurity and for considering the institutional and governance arrangements that are needed to exercise and sustain them [31]."

From those three discourse narrations above, it can be understood that human security is a security concept which is constructed through inclusion/exclusion articulation structure from three contexts. First, the existence of human security as a security concept is inseparable from the inclusion of meaning; any things that are interpreted as threats in state security context are also interpreted as threats for human life. That inclusion can occur because every human body/population in the nation-states is the UN's power subject. Furthermore, the existence of nation-states as constituents or members of the UN also put nation-states as the UN's power subject. It allows the UN to include everything which is being articulated by states as threats toward human life into human security concept.

Second, the existence of human security as a security concept is inseparable from the inclusion of meaning over economic security and threats that are contained in the human development context. That inclusion is possible because of conflicts that are related to economic problems, such as the seizure of natural resources, crisis, famine, poverty, and other things that potentially become threats for human life. Therefore, human security includes meaning over economic security and threats which are contained in the human development context so that the existence is able to give meanings of what a safe human life is.

Third, human security includes meanings over the threat of conflicts and violence which may appear because of tyranny and the seizure of human rights in a certain state. That inclusion is possible through two conditioning or circumstancing processes. First, human in certain circumstance, like refugees and asylum seekers, can be subjects in the UN's power. The second one, as the consequence of the UN's arrangement which positioned human rights as a universal value, any threats that potentially threaten the seizure of human rights are considered as threats that can be included in the UN's authority scope and are integrated as a security concept of human security.

Based on the three threat inclusions above, the UN has the scope to decide what can be done in order to deal with those threats. In fact, the three threats in state security, human development, and human rights can be the UN's rationality foundation to intervene on behalf of humanity. It is possible to be conditioned based on the UN's juridical formation that assigns the UN's roles and goals which can cover those threats.

\section{CONCLUSION}

The UN is able to make human security as a security concept based on three conditions. The first is the UN's power subject condition which includes four levels allows the UN to rationalize security for human's life in totality. These four power subject levels are individuals; individual set of bodies that has joined in a social group; individual body population that is collected through national identity construction and has their own way to decide their own fate through nation-states' political order; and a set of various bodies/populations with varieties of different national identity as international society. Second, biopolitical production in the UN juridical formation gives rationality foundation to convince everybody/population from nation-states to be constituents or the UN members, run the UN's functions, and work together to reach the UN's goals, especially the one that is related to human rights and human development. Third, human security concept is defined by inclusion/exclusion structure inclusion which includes state security threats, human rights, and human development that has already existed in the UN juridical formation, so that the UN has a rationality foundation to set human security as an international security agenda, even though the human security concept is beyond the security agenda which is always mentioned in the UN Charter.

The emergence of human security as a security concept cannot be separated from political power relation to organizing the benefit of human life. In this case, the UN tries to underline its power as a global political institution that is able to maintain human life from various threats which can damage their very life. The construction of the human security concept has two meaning consequences that have implications for human life globally. On one side, human security concept gives meaning to the power's space for the global political institution to act as a guard to maintain people's life from structural threats that are appeared and encouraged by a nonglobal political entity like state, which can obstruct human rights fulfillment and welfare attainment. On the other side, the human security concept can act as rationality foundation for political power contests between states which allow any sovereignty interventions in the name of human life. These two consequences, obviously, cannot be separated from people's social, political, and economic life; like two sides of the coin. These two consequences can be a knowledge basis for every academics, state leaders, groups with interest, and 
people in general in interpreting or evaluating the good and bad from the global political institution power practices, and political contests between states on behalf of human life.

\section{REFERENCES}

[1] W. B. Gallie, "Essentially Contested Concepts," in Proceedings of the Aristotelian Society, New Series, 56: pp. 167-198. Oxford: Oxford University Press, 1956. pp. 184.

[2] H. G. Brauch, "Security and Environment Linkages in the Mediterranean: Three Phases of Research on Human and Environmental Security and Peace." In: Brauch, Hans Günter; Liotta, P.H.; Marquina, Antonio/Rogers, Paul; Selim, Mohammed El-Sayed (Eds.): Security and Environment in the Mediterranean: Conceptualizing Security and Environmental Conflicts. Berlin - Heidelberg: Springer, 2003: 35-143. pp. 52 .

[3] W. B. Gallie, "Essentially Contested Concepts," in Proceedings of the Aristotelian Society, New Series, 56: pp. 167-198. Oxford: Oxford University Press, 1956. pp. 52.

[4] B. Buzan, People, States \& Fear: The National Security Problem in International Relations. 2nd edition. New Jersey: Financial Times Prentice Hall, 1991. pp. 370.

[5] H. G. Brauch, "Security and Environment Linkages in the Mediterranean: Three Phases of Research on Human and Environmental Security and Peace." In: H.G. Brauch, P.H. Liotta, et al. (Eds.): Security and Environment in the Mediterranean: Conceptualizing Security and Environmental Conflicts. Berlin - Heidelberg: Springer, 2003: 35-143. pp. 52.

[6] M. Foucault, The Birth Of Biopolitics: Lectures At The College De France, 1978-1979. (Ed): Arnold I. Davidson. New York: Palgrave Macmillan, 2008; G. Agamben, Homo Sacer: Sovereign Power and Bare Life, trans. D. Heller-Roazen. California: Stanford University Press, 1995; T. Lemke, Biopolitics: An Advanced Introduction, terj. E. Trump New York \& London: New York University Press, 2011.

[7] R.B.J. Walker, After The Globe, Before The World. New York: Routledge, 2009; R.B.J. Walker, "International/Inequality," International Studies Review, Vol. 4, No.2 Summer, 2002: pp. 7-24.

[8] Human Security Unit, Human Security in Theory and Practice. New York: United Nations, 2009. pp. 8; Human Security Unit, Human Security Unit Strategic Plan 2014-2017 (New York: United Nations, 2014. pp. 4.

[9] Human Security Unit, Office for The Coordination of Humanitarian Affairs, Human Security For All, Integrated Responses to Protect and Empower People and Communities: A Look at Nine Promising Efforts. New York: United Nations, 2006. pp. 2-3.

[10] Commission on Human Security (CHS), Human Security Now. New York: United Nations, 2003. pp. 2-4.
[11] Human Security Unit, Human Security in Theory and Practice. New York: United Nations, 2009. pp. 8.

[12] The United Nations Charter Article 1

[13] The United Nations Charter Article 34

[14] R.B.J. Walker, After The Globe, Before The World. New York: Routledge, 2009; R.B.J. Walker, "International/Inequality," International Studies Review, Vol. 4, No.2 Summer, 2002: pp. 7-24.

[15] M. Hardt, \& A. Negri, Empire.London: Harvard University Press, 2000. pp. 24

[16] T. Lemke, Biopolitics: An Advanced Introduction, Trans. Erick Trump. New York \& London: New York University Press, 2011. pp. 33-39.

[17] T. Lemke, Biopolitics: An Advanced Introduction, Trans. Erick Trump. New York \& London: New York University Press, 2011. pp. 47.

[18] T. Lemke, Biopolitics: An Advanced Introduction, Trans. Erick Trump. New York \& London: New York University Press, 2011. pp. 33-39.

[19] M. Foucault, The Birth Of Biopolitics: Lectures At The College De France, 1978-1979. (Ed): Arnold I. Davidson. New York: Palgrave Macmillan, 2008. pp. 37.

[20] M. Hardt, \& A. Negri, Empire.London: Harvard University Press, 2000. pp. 5

[21] The United Nations Charter Article 1.

[22] M. Foucault, The Birth Of Biopolitics: Lectures At The College De France, 1978-1979. (Ed): Arnold I. Davidson. New York: Palgrave Macmillan, 2008; G. Agamben, Homo Sacer: Sovereign Power and Bare Life, trans. D. Heller-Roazen. California: Stanford University Press, 1995 pp. 42.

[23] See United Nations, General Assembly resolution 217A (III) of 10 December 1948: Universal Declaration of Human Rights, in the first, second, and third paragraph of the preamble.

[24] See United Nations, General Assembly resolution 2200A (XXI) of 16 December 1966: International Covenant on Economic, Social and Cultural Rights, in the third paragraph of the preamble.

[25] Millennium Development Goals (MDGs), accessed on December $18^{\text {th }}$, 2016 at 16.05, https://www.oecd.org/dac/2754929.pdf

[26] R.B.J. Walker, “International/Inequality,” International Studies Review, Vol. 4, No.2 (Summer, 2002): p. 7-24.

[27] R.B.J. Walker, After The Globe, Before The World. New York: Routledge, 2009. pp. 33.

[28] R.B.J. Walker, After The Globe, Before The World. New York: Routledge, 2009. pp. 10.

[29] Human Security Unit, Human Security For All, Integrated Responses to Protect and Empower People and Communities: A Look at Nine Promising Efforts. New York: United Nations, 2006. pp. 2-3.

[30] Human Security Unit, Human Security in Theory and Practice New York: United Nations, 2009. pp. 8.

[31] Human Security Unit, Human Security in Theory and Practice New York: United Nations, 2009. pp. 8. 